\title{
Intraocular acyclovir levels after subconjunctival and topical administration
}

\author{
JOEL SCHULMAN,' GHOLAM A PEYMAN, ${ }^{2}$ RICHARD FISCELLA, ${ }^{2}$ \\ DAVID GREENBERG, ${ }^{2}$ MARK B HORTON,' AND PAUL DE MIRANDA ${ }^{3}$
}

From the Departments of Ophthalmology, ${ }^{2}$ University of Illinois at Chicago, and 'University of Texas Medical Branch, Galveston, and ${ }^{3}$ Burroughs-Wellcome Laboratories, Research Triangle Park, North Carolina

SUMMARY Substantial levels of acyclovir were detected in the aqueous and vitreous of New Zealand rabbits at various time intervals following subconjunctival injection. Intravitreal penetration of acyclovir after topical application was poor.

Acyclovir is an antiviral agent that possesses substantial activity and specificity against most members of the herpes simplex virus family with the possible exception of cytomegalovirus.' Acyclovir shows little toxicity toward uninfected human cells. ${ }^{2}$ This preliminary study was designed to evaluate the intraocular levels of the drug at different time intervals following subconjunctival injection and topical administration. To the best of our knowledge no other report describes intraocular penetration of acyclovir following subconjunctival administration or vitreous levels after topical application of acyclovir.

\section{Materials and methods}

A total of 47 New Zealand white rabbits, weighing approximately $2 \mathrm{~kg}$ each, were divided into three groups for this study.

Part $A$. The animals were anaesthetised with an intravenous injection of ketamine hydrochloride. A single $25 \mathrm{mg}$ injection of acyclovir sodium $(0.5 \mathrm{ml}$ of a $50 \mathrm{mg} / \mathrm{ml}(50 \mathrm{~g} / \mathrm{l})$ solution) was given under the bulbar conjunctiva of one eye of each rabbit. At 1, 3, 5, and 24 hours after subconjunctival injection aqueous and vitreous samples were removed and immediately refrigerated at $-27 \mathrm{C}$. Each sample of aqueous was obtained with a 30-gauge needle inserted through clear cornea. Vitreous samples were aspirated with a 23-gauge needle placed $2 \mathrm{~mm}$ behind the limbus. Levels of acyclovir were determined by radioimmunoassay. ${ }^{3}$

Part $B$. The experiment was repeated with a $2.5 \mathrm{mg}$ injection of acyclovir $(0.5 \mathrm{ml}$ of a $5 \mathrm{mg} / \mathrm{ml}(5 \mathrm{~g} / \mathrm{l})$

Correspondence to Joel Schulman, MD, UTMB Department of Ophthalmology, Galveston. Texas 77550. USA. solution) under the bulbar conjunctiva of one eye of each rabbit. Aqueous $(0 \cdot 1 \mathrm{ml})$ and vitreous $(0.1 \mathrm{ml})$ samples were obtained in the same fashion as in part $A$ at $0 \cdot 5,1,2,3$, and 22 hours after subconjunctival injection.

Part C. One eye from each of 10 rabbits was treated with $3 \%$ acyclovir ointment. A $1 \mathrm{~cm}$ ribbon of the ointment was placed in the inferior cul de sac of each eye every five hours for 25 hours. A total of six applications were given to each eye. At 1,2 , and 3 hours after the last application of acyclovir vitreous samples were obtained and immediately refrigerated at $-27^{\circ} \mathrm{C}$. Acyclovir levels were determined by radioimmunoassay.

\section{Results}

Part $A$. Clinically the rabbits showed crystallisation of acyclovir after subconjunctival injection. The crystals dissolved within 18 hours. Minimal conjunctival reaction followed the injection. Relatively high aqueous (Table 1) and vitreous (Table 2) levels of acyclovir were detected after subconjunctival injection.

Part $B$. Sunconjunctival crystallisation of acyclovir was not detected in this group. Substantial aqueous (Table 3) and vitreous (Table 4) levels of acyclovir were obtained.

Part C. Vitreous levels following topical application of the drug were negligible (Table 5).

\section{Discussion}

Acyclovir, 9-(2-hydroxyethoxymethyl)guanine, is also called acycloguanosine. ${ }^{45}$ In-vitro acyclovir is 
Table 1 Acyclovirlevels in rabbit aqueous humour

\begin{tabular}{|c|c|c|c|}
\hline \multirow[b]{3}{*}{ Time (h) } & \multicolumn{3}{|c|}{ Aqueous humour samples } \\
\hline & \multirow[b]{2}{*}{ Sample } & \multicolumn{2}{|c|}{ Concentration } \\
\hline & & $\mu g / m l$ & $\mu M$ \\
\hline \multirow[t]{3}{*}{$1 \cdot 0$} & A1 & $258 \cdot 84$ & $1150 \cdot 38$ \\
\hline & A2 & $533 \cdot 13$ & $2369 \cdot 43$ \\
\hline & $\mathrm{A} 3$ & 137.83 & 612.59 \\
\hline \multirow[t]{3}{*}{$3 \cdot 0$} & A4 & $104 \cdot 42$ & 464.07 \\
\hline & A5 & $297 \cdot 42$ & $1321 \cdot 86$ \\
\hline & A6 & $199 \cdot 32$ & 885.87 \\
\hline \multirow[t]{3}{*}{$5 \cdot 0$} & A7 & $71 \cdot 50$ & $316 \cdot 23$ \\
\hline & A8 & $102 \cdot 49$ & $455 \cdot 50$ \\
\hline & A9 & 82.55 & 366.88 \\
\hline \multirow[t]{3}{*}{$24 \cdot 0$} & $\mathrm{~A} 10$ & 2.08 & $9 \cdot 25$ \\
\hline & A11 & 3.43 & $15 \cdot 24$ \\
\hline & A12 & 1.72 & $7 \cdot 62$ \\
\hline
\end{tabular}

Samples were obtained after rabbits received a subconjunctival injection of $25 \mathrm{mg}(\theta \cdot 5 \mathrm{ml})$ of acyclovir sodium salt.

Table 2 Acyclovir levels in rabbit vitreous humour

\begin{tabular}{|c|c|c|c|}
\hline \multirow[b]{3}{*}{ Time $(h)$} & \multicolumn{3}{|c|}{ Vitreous humour samples } \\
\hline & \multirow[b]{2}{*}{ Sample } & \multicolumn{2}{|c|}{ Concentration } \\
\hline & & $\mu g / m l$ & $\mu M$ \\
\hline \multirow[t]{2}{*}{$1 \cdot 0$} & V1 & $2 \cdot 31$ & $10 \cdot 27$ \\
\hline & $\mathrm{V} 2$ & 4.73 & 21.03 \\
\hline \multirow[t]{3}{*}{$3 \cdot 0$} & V3 & 1.61 & $7 \cdot 17$ \\
\hline & V4 & 23.02 & $102 \cdot 30$ \\
\hline & V5 & $34 \cdot 79$ & 154.62 \\
\hline \multirow[t]{3}{*}{$5 \cdot 0$} & V6 & 65.95 & 293.09 \\
\hline & V7 & 15.44 & 68.62 \\
\hline & V8 & 32.58 & 144.78 \\
\hline \multirow[t]{4}{*}{$24 \cdot 0$} & V9 & 0.21 & 0.95 \\
\hline & V10 & $0 \cdot 13$ & $0 \cdot 57$ \\
\hline & V11 & 0.22 & 0.99 \\
\hline & V12 & $0 \cdot 31$ & $1 \cdot 32$ \\
\hline
\end{tabular}

Samples were obtained after rabbits received a subconjunctival injection of $25 \mathrm{mg}(0 \cdot 5 \mathrm{ml})$ of acyclovir sodium salt.

active against DNA viruses of the herpes group. ${ }^{46}$ Because acyclovir is activated in vivo only by virusspecific enzymes, it is non-toxic to uninfected cells. ${ }^{2}$

In-vitro acyclovir has been found to be effective against several members of the herpes virus family. Minimum inhibitory concentrations (MIC) of acyclovir have been reported as $0 \cdot 2,0 \cdot 4,1 \cdot 0,1 \cdot 5$, and $16 \cdot 3 \mu \mathrm{g} / \mathrm{ml}(\mathrm{mg} / \mathrm{l})$ for herpes simplex virus type I (HSV-I), herpes simplex virus type II (HSV II), varicella zoster virus (VZV), Epstein-Barr virus (EBV), and cytomegalovirus (CMV) respectively. ${ }^{4}$ The ID $_{50}(50 \%$ inhibitory dose $)$ in herpes virus isolated from human infections was $0.15 \mathrm{SD} 0.09 \mu \mathrm{M}$, $1.62 \mathrm{SD} 0.76 \mu \mathrm{M}$, and $3.75 \mathrm{SD} 1.30 \mu \mathrm{M}$ for HSV I, HSV II, and VZV. Two CMV isolates had $\mathrm{ID}_{50} \mathrm{~S}$ of 100 and $160 \mu \mathrm{M}$, while four other isolates showed no plaque reduction at $200 \mu \mathrm{M}^{2}$
Table 3 Acyclovir levels in rabbit aqueous humour

\begin{tabular}{llrr}
\hline \multicolumn{5}{c}{ Aqueous humour samples } \\
\cline { 3 - 4 } Time $(h)$ & \multicolumn{3}{c}{ Concentration } \\
\cline { 3 - 4 } & Sample & $\mu g / m l$ & $\mu M$ \\
\hline 0.5 & A1 & 1.13 & 5.04 \\
& A2 & 2.98 & 13.20 \\
& A3 & $>45.00$ & $>200.00$ \\
1.0 & A4 & $>45.00$ & $>200.00$ \\
& A5 & 16.00 & 71.10 \\
& A6 & 9.36 & 41.60 \\
2.0 & A7 & 4.04 & 17.90 \\
& A8 & 7.87 & 35.00 \\
3.0 & A9 & 9.41 & 41.80 \\
& A10 & 3.27 & 14.50 \\
& A11 & 5.59 & 24.90 \\
22.0 & A12 & 9.19 & 40.09 \\
& A13 & $<0.56$ & $<2.50$ \\
& A14 & $<0.56$ & $<2.50$ \\
\hline
\end{tabular}

Samples were obtained after rabbits received a subconjunctival injection of $2.5 \mathrm{mg}(0.5 \mathrm{ml})$ acyclovir.

Table 4 Acyclovir levels in rabbit vitreous humour

\begin{tabular}{|c|c|c|c|}
\hline \multirow[b]{3}{*}{ Time (h) } & \multicolumn{3}{|c|}{ Vitreous humour samples } \\
\hline & \multirow[b]{2}{*}{ Sample } & \multicolumn{2}{|c|}{ Concentration } \\
\hline & & $\mu g / m l$ & $\mu M$ \\
\hline \multirow[t]{3}{*}{0.5} & V1 & $6 \cdot 28$ & 27.90 \\
\hline & $\mathrm{V} 2$ & 0.90 & 3.98 \\
\hline & V3 & 0.62 & $2 \cdot 76$ \\
\hline \multirow[t]{3}{*}{1.0} & V4 & 0.95 & $4 \cdot 23$ \\
\hline & V5 & $1 \cdot 17$ & $5 \cdot 21$ \\
\hline & V6 & $2 \cdot 70$ & $12 \cdot 00$ \\
\hline \multirow[t]{3}{*}{$2 \cdot 0$} & V7 & 1.43 & $6 \cdot 36$ \\
\hline & V8 & $<0.56$ & $<2 \cdot 50$ \\
\hline & V9 & $1 \cdot 30$ & $5 \cdot 78$ \\
\hline \multirow[t]{3}{*}{$3 \cdot 0$} & V10 & $1 \cdot 88$ & $8 \cdot 39$ \\
\hline & V11 & $1 \cdot 36$ & 6.06 \\
\hline & V12 & 0.92 & 4.09 \\
\hline \multirow[t]{2}{*}{$22 \cdot 0$} & V13 & $<0.56$ & $<2.50$ \\
\hline & V14 & $<0.56$ & $<2 \cdot 50$ \\
\hline
\end{tabular}

Samples were obtained after rabbits received a subconjunctival injection of $2.5 \mathrm{mg}(0.5 \mathrm{ml})$ acyclovir.

Topical application of acyclovir resulted in vitreous levels well below the therapeutic range for members of the HSV family. Subconjunctival injection with $25 \mathrm{mg}$ of the sodium salt of acyclovir produced, in most instances, aqueous and vitreous levels sufficient to inhibit members of the HSV family with the possible exception of CMV. The vitreous acyclovir levels remained in therapeutic proportions for at least three hours after injection. Therapeutic aqueous levels for HSV I and HSV II were present at 18 hours after injection, but vitreous levels were subtherapeutic for all members of the HSV family except HSV I. The variation in acyclovir levels probably resulted in part from an uneven absorption 
Table 5 Acyclovir levels in rabbit vitreous humour

\begin{tabular}{|c|c|c|c|}
\hline \multirow[b]{3}{*}{ Time (h) } & \multicolumn{3}{|c|}{ Vitreous humour samples } \\
\hline & \multirow[b]{2}{*}{ Sample } & \multicolumn{2}{|c|}{ Concentration } \\
\hline & & $\mu g / m l$ & $\mu M$ \\
\hline \multirow[t]{3}{*}{$1 \cdot 0$} & V1 & $<0.02$ & $<0 \cdot 10$ \\
\hline & $\mathrm{V} 2$ & $<0.03$ & $<0 \cdot 10$ \\
\hline & V3 & $<0.02$ & $<0 \cdot 10$ \\
\hline \multirow[t]{3}{*}{$2 \cdot 0$} & V4 & 0.03 & $0 \cdot 12$ \\
\hline & V5 & $<0.02$ & $<0 \cdot 10$ \\
\hline & V6 & 0.02 & $0 \cdot 10$ \\
\hline \multirow[t]{4}{*}{$3 \cdot 0$} & V7 & $<0.02$ & $<0 \cdot 10$ \\
\hline & V8 & 0.04 & $0 \cdot 18$ \\
\hline & V9 & $<0.02$ & $<0 \cdot 10$ \\
\hline & V10 & 0.02 & $0 \cdot 10$ \\
\hline
\end{tabular}

Samples were obtained after rabbits received a topically applied $1 \mathrm{~cm}$ ribbon of $3 \%$ acyclovir every five hours for a total of six applications over a 25-hour period.

due to crystallisation from the subconjunctival injection. This occurred only with the higher dose of acyclovir.

The second part of the experiment (subconjunctival injection of $2.5 \mathrm{mg}$ of acyclovir) produced aqueous levels in excess of the MIC for all members of the HSV family except CMV for at least three hours after injection. Negligible levels of acyclovir were detectable 22 hours after injection. Vitreous levels were therapeutic for HSV I, HSV II, VZV, and EBV, but not CMV during the first three hours after injection.

Patients with herpes simplex retinitis have had substantial visual loss and retinal damage..$^{7-11} \mathrm{~A}$ recent communication ${ }^{12}$ has suggested an association between acute retinal necrosis and HSV infection. HSV has been demonstrated in the anterior chamber in iritis, keratouveitis, and disciform corneal oedema with associated iritis. ${ }^{13-15}$ Herpes virus particles also have been detected in an iridectomy specimen removed from a patient with herpetic uveitis, deep keratitis, and secondary glaucoma. ${ }^{16}$ Our findings indicate that subconjunctival injection of acyclovir may provide effective drug levels for the primary or adjunctive treatment of deep herpetic disease such as retinitis, keratouveitis, iritis, and possibly acute retinal necrosis. Caution must be exercised, how- ever, in making recommendations based on data obtained only from rabbit eyes. Subconjunctival acyclovir infection should avoid toxic reactions reported after parenteral administration.

This work was supported in part by core grant IP3EY01792 from the National Institutes of Health, Bethesda, Md.

\section{References}

1 Hopefl AW. The clinical use of intravenous acyclovir. Drug Intell Clin Pharm 1983; 17: 623-8.

2 Crumpacker CS, Schnipper LE, Zaia J, Levin, MJ. Growth inhibition by acycloguanosine of herpesviruses isolated from human infections. Antimicrob Agents Chemother 1979; 15: $642-5$.

3 Quinn RP, de Miranda P, Gerald L, Good SS. A sensitive radioimmunoassay for the antiviral agent BW2480 (9-[2hydroxymethyl] guanine). Anal Biochem 1979; 98: 319-28.

4 Rosenberry KR, Bryan CK, Sohn CA. Acyclovir evaluation of a new antiviral agent. Clin Pharmacy 1982; 1: 399-406.

5 Liu M. Antiviral drugs. Med Clin North Am 1982; 66: 235-44.

6 Schaeffer HJ, Beauchamp L, De Miranda P, et al. 9-(2Hydroxyethoxymethyl)guanine activity against viruses of the herpes group. Nature 1978; 272: 583-5.

7 Pepose JS, Hilborne LH, Cancilla PA, Foos RY. Concurrent herpes simplex and cytomegaloviris retinitis and encephalitis in the acquired immune deficiency syndrome (AIDS). Ophthalmology (Rochester) 1984; 91: 1669-77.

8 Partamian LG, Morse PH, Klein HZ. Herpes simplex type 1 retinitis in an adult with systemic herpes zoster. Am J Ophthalmol 1981; 92: 215-20.

9 Cibis GW, Flynn JT, Davis EB. Herpes simplex retinitis. Arch Ophthalmol 1978; 96: 299-302.

10 Minckler DS, McLean EB, Shaw CM, Hendrickson A. Herpesvirus hominis encephalitis and retinitis. Arch Ophthalmol 1976; 94: 89-95.

11 Bloom JN, Katz JI, Kaufman HE. Herpes simplex retinitis and encephalitis in an adult. Arch Ophthalmol 1977; 95: 1798-9.

12 Ludwig IH, Zegarra $\mathrm{H}$, Zakov $\mathrm{ZN}$. The acute retinal necrosis syndrome: possible herpes simplex retinitis. Ophthalmology (Rochester) 1984; 91: 1659-64.

13 Kaufman HE, Kanai A, Ellison ED. Herpetic iritis: demonstration of virus in the anterior chamber by fluorescent antibody techniques and electron microscopy. Am J Ophthalmol 1971; 71: 465-9.

14 Jones BR, Patterson A, Rice NSC. Symposium on certain forms of infective kerato-uveitis or uveitis: I. An approach to the problem and the technique of anterior chamber tap. Trans Ophthalmol Soc UK 1968; 88: 235-42.

15 Kaufman HE. Herpetic stromal disease. Am J Ophthalmol 1975; 80: $1092-4$.

16 Witmer R, Iwamoto T. Electron microscope observations of herpes-like particles in the iris. Arch Ophthalmol 1968; 79: 331-7.

Accepted for publication 24 May 1985. 